\title{
INTERACTION BETWEEN PYOCIN R AND PYOCIN R RECEPTOR $^{1}$
}

\author{
KAYOKO IKEDA² AND YOSHIMI NISHI* \\ Department of Biophysics and Biochemistry, Faculty of Science, \\ University of Tokyo, Tokyo 113 \\ and \\ *Laboratory of Ultrastructure Research, Research Institute, \\ Aichi Cancer Center, Nagoya 464
}

(Received December 1, 1972)

\begin{abstract}
1) Pyocin R-sensitive cells were digested with lysozyme in the presence of EDTA in hypertonic solution. Most of the receptor activity was solubilized, by this procedure, and separated from spheroplast membrane fraction. This suggested the location of receptor on the cell wall.

2) Electron microscopic figure revealed the adsorption of pyocin $R$ on the cell surface and its fragment. Pyocin particles were adsorbed on the receptor site with the contracted sheath, at the tip of core.

3) Properties of interaction between pyocin $R$ and its receptor were studied. Pyocin $\mathrm{R}$ inactivation by its adsorption to the receptor was highly dependent on temperature, and the presence of $0.1-0.2 \mathrm{M} \mathrm{NaCl}$ was necessary for the optimal inactivation.

4) Size of receptor site required for the inactivation of a pyocin particle was estimated.
\end{abstract}

Pyocin R is adsorbed on some strains of Pseudomonas aeruginosa and kills the bacterium by a single-hit killing process (1). About the action mechanism of pyocin R, KAZIRO and TANAKA reported that the pyocin $\mathrm{R}$ infection caused the complete stop of macromolecule synthesis and the degradation of ribosomes $(2,3)$.

At the infection of bacteriocin such as colicin, the first step is considered to be the adsorption of the particle to the specific receptor site on the cell surface, but there has been no direct information about the chemical nature of the receptor and the interaction between the bacteriocin and the receptor.

In the previous papers, the preparation and chemical properties of pyocin

1 This constitutes Part III of a series entitled "Studies on Receptor Substance for Pyocin R".

2 Present address: Department of Neuropharmacology, Brain Research Institute, Niigata University, Niigata 951. 
$\mathrm{R}$ receptor substance from $P$. aeruginosa were described $(4,5)$. The chemical nature of the receptor substance was proved to be a lipopolysaccharide which could reversibly dissociate into smaller subunits (5). These results are similar to the observation that the receptor substance of $E$. coli T-series phages are lipopolysaccharide in nature (6-9).

In this paper we describe the properties of pyocin $\mathrm{R}$ inactivation reaction caused by the adsorption of pyocin $\mathrm{R}$ to the receptor.

\section{MATERIALS AND METHODS}

Receptor substance. The fraction designated as $130 \mathrm{P}$ in a previous paper (4) extracted from Pseudomonas aeruginosa strain P11 by a trichloroacetic acid method and sedimented between 14,000 and $130,000 \times g$ was used. Preparation 1 of the lipopolysaccharide which was extracted from $P$. aeruginosa P14 by the combination of trichloroacetic acid and phenol method (5) was also used.

Assay of receptor activity. Receptor activity was usually measured by the method previously described (4). A solution of the receptor substance was serially diluted by two-fold, and $0.2 \mathrm{ml}$ of the diluted solution was incubated with $0.1 \mathrm{ml}$ of pyocin solution $\left(\mathrm{OD}_{280}=0.06\right)$ in the final volume of 0.5 ml. Remaining pyocin activity was measured and the maximum dilution number which showed the inhibition of pyocin activity was expressed as the receptor activity. In the experiments shown by Figs. 3 and 4, excess of pyocin was incubated with a small amount of the receptor, and the remaining pyocin activity was measured by the serial dilution method (10).

Fractionation of cell wall and spheroplast membrane. Subcellular fraction was prepared according to the procedure of YosHIDA et al. (11), with a slight modification of incubation condition. Cells of pyocin R-sensitive strain ( $P$. aeruginosa $\mathrm{P} 11$ or P14) were harvested at their logarithmic phase, washed

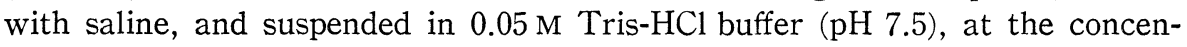
tration of $100 \mathrm{mg}$ wet weight cells per $\mathrm{ml}$ of the solution. One volume of EDTA solution $(3.2 \mathrm{mg} / \mathrm{ml}$ in the above buffer) to the cell suspension, equal volume of lysozyme solution ( $300 \mu \mathrm{g} / \mathrm{ml}$ in the above buffer), and three volumes of $1 \mathrm{M}$ sucrose (or $1 \mathrm{M} \mathrm{KCl}$ ) solution were mixed and added to one volume of the cell suspension. After incubation was done at $30^{\circ}$ or $37^{\circ}$ with standing, lysozyme-digested cells (spheroplast suspension) were centrifuged down for 10 min at 14,000 rpm. A spheroplast supernatant fraction and a spheroplast fraction were obtained. Spheroplasts were suspended in 2 volumes of lysis buffer per original cell suspension and kept standing for $15 \mathrm{~min}$ at room temperature. Lysis buffer contained $20 \mu \mathrm{g}$ DNase 1 per $\mathrm{ml}$ of $0.05 \mathrm{M}$ Tris- $\mathrm{HCl}$ and $0.05 \mathrm{mM}$ $\mathrm{MgCl}_{2}$ solution. "Cell shockate" was formed and centrifuged for $10 \mathrm{~min}$ at $14,000 \mathrm{rpm}$. The supernatant fraction was saved and the precipitated spheroplast membrane fraction was resuspended in a mixture of $0.05 \mathrm{M} \mathrm{Tris}-\mathrm{HCl}$ 
( $\mathrm{pH} 7.5$ ), $0.05 \mathrm{M} \mathrm{MgCl}_{2}$. At every step, a portion of the sample was reserved and receptor activity was measured.

Electron microscopy. Negatively stained specimens were prepared as follows. Samples were mixed with an equal volume of $2 \%$ sodium phosphotungstate ( $\mathrm{pH} \mathrm{7.0)}$ and a drop of the mixture was deposited on a formvalcoated grid. After a few minutes the excess solution was blotted with a filter paper and the specimens were examined in a Hitachi model HU-11B electron microscope at a direct magnification of 50,000 .

Chemicals. Lysozyme (EC 3.2.1.17) and DNase 1 (EC 3.3.4.5) were purchased from Seikagaku Kogyo Co., Ltd., Tokyo.

Other experimental methods were the same as those described in the previous paper (5).

\section{RESULTS}

\section{Distribution of the receptor activity in the subcellular fraction}

Cell surface components of $P$. aeruginosa were fractionated into those derived from cell wall and spheroplast membrane fraction, as described above. The receptor activity recovered in the fractionation steps is shown in Table 1. Cells of $P$. aeruginosa were readily lysed and incubation conditions for preparing spheroplast were examined in several ways. Table 1 shows the typical results.

Wet cells in 800,400 , and $300 \mathrm{mg}$ were used in the experiments 1,2 , and 3 , respectively, and the total activities were calculated. Receptor activity of the intact cell suspension was recovered in subcellular fractions with good yield. By the limitation of assay accuracy (activity was expressed as $2^{n}$ ), an apparent increase of activity was observed in experiment 2 . Dominant receptor activity was found in the spheroplast supernatant fraction, which was mainly composed of solubilized cell wall. The activity of solubilized fraction increased with the incubation time or by the incubation at higher temperature, and a very small activity was found in spheroplast membrane fraction, in experiment 3 .

\section{Electron microscopic observation}

Electron microscopic observation previously revealed that the pyocin particle had a structure which resembled the T-even phage tail (12). The main structure is a double hollow cylinder, $1,200 \AA$ long and $150 \AA$ in outer diameter, which consisted of a sheath and a core. Pyocin $\mathrm{R}$ was incubated with P11 cells and its electron microscopic figure revealed the attachment of pyocin particles on the cell surface (Fig. 1). Pyocin particles were attached to the bacterial surface with the contracted sheath and adsorbed at the tip of core. Because of the dilution with water before making the specimen, cell lysis was observed.

A figure of the pyocin $\mathrm{R}$ adsorption on the spheroplast membrane fraction 
Table 1. Distribution of receptor activity.

Subcellular fractions were made according to the method described in the text. In the experiments 1 and $2,3.2 \mathrm{mg} / \mathrm{ml}$ of EDTA solution was used and in the experiment $3,6.4 \mathrm{mg} / \mathrm{ml}$ was used. Receptor activity was measured by serial dilution of $0.2 \mathrm{ml}$ portion of the sample, and expressed as the total activity units.

\begin{tabular}{|c|c|c|c|}
\hline & \multicolumn{3}{|c|}{ Exp. No. } \\
\hline & 1 & 2 & 3 \\
\hline \multirow{3}{*}{$\begin{array}{l}\text { Strain (wet weight of cells) } \\
\text { Incubation conditions for } \\
\text { preparation of spheroplast }\end{array}$} & $\mathrm{P} 11 \quad(800 \mathrm{mg})$ & P14 (400 mg) & P14 (300 mg) \\
\hline & $37^{\circ}, 30 \mathrm{~min}$ & $30^{\circ}, 40 \mathrm{~min}$ & $37^{\circ}, 40 \mathrm{~min}$ \\
\hline & \multicolumn{3}{|c|}{ Total receptor activity } \\
\hline $\begin{array}{l}\text { Cell suspension } \\
\text { (Spheroplast) }\end{array}$ & 10,240 & 3,072 & 3,840 \\
\hline Spheroplast suspension & 6,275 & 6,144 & 3,840 \\
\hline Supernatant & 4,480 & 3,072 & 2,880 \\
\hline Spheroplast & - & 2,560 & 720 \\
\hline \multicolumn{4}{|l|}{ (Cell shockate) } \\
\hline Supernatant & 1,535 & 640 & 480 \\
\hline Spheroplast membrane fraction & 1,790 & 1,280 & 280 \\
\hline
\end{tabular}

- not determined.

is shown in Fig. 2. Spheroplast was prepared as described above and, in this preparation, hypertonic solution was made with $\mathrm{KCl}$ and incubation time was $30 \mathrm{~min}$. Adsorption of pyocin $\mathrm{R}$ with contracted sheath can be seen more clearly. In the figures obtained by this preparation, pyocin was not adsorbed on the whole surface of membrane fraction itself, but was attached to smaller particles or localized site of the membrane. Pyocin particles may be adsorbed on the remaining cell wall component in the membrane fraction, as suggested from the result of Table 1 .

Similar morphological change of pyocin $\mathrm{R}$ was observed by incubation with the receptor substance of $130 \mathrm{P}$ fraction, while no such change was observed with the same preparation from pyocin R-resistant strain $\mathrm{P} 1$.

\section{Properties of pyocin $R$ inactivation reaction}

Properties of pyocin $\mathrm{R}$ inactivation reaction by the adsorption of pyocin $\mathrm{R}$ to the receptor were studied. Receptor activity of reassociated lipopolysaccharide free from aminosugar-rich fraction, described in the preceding paper, was low and unstable (5), therefore, 130 $\mathrm{P}$ fraction and "preparation 1 " in the previous papers $(4,5)$ were used.

Dependency of the inactivation reaction on the receptor concentration is 


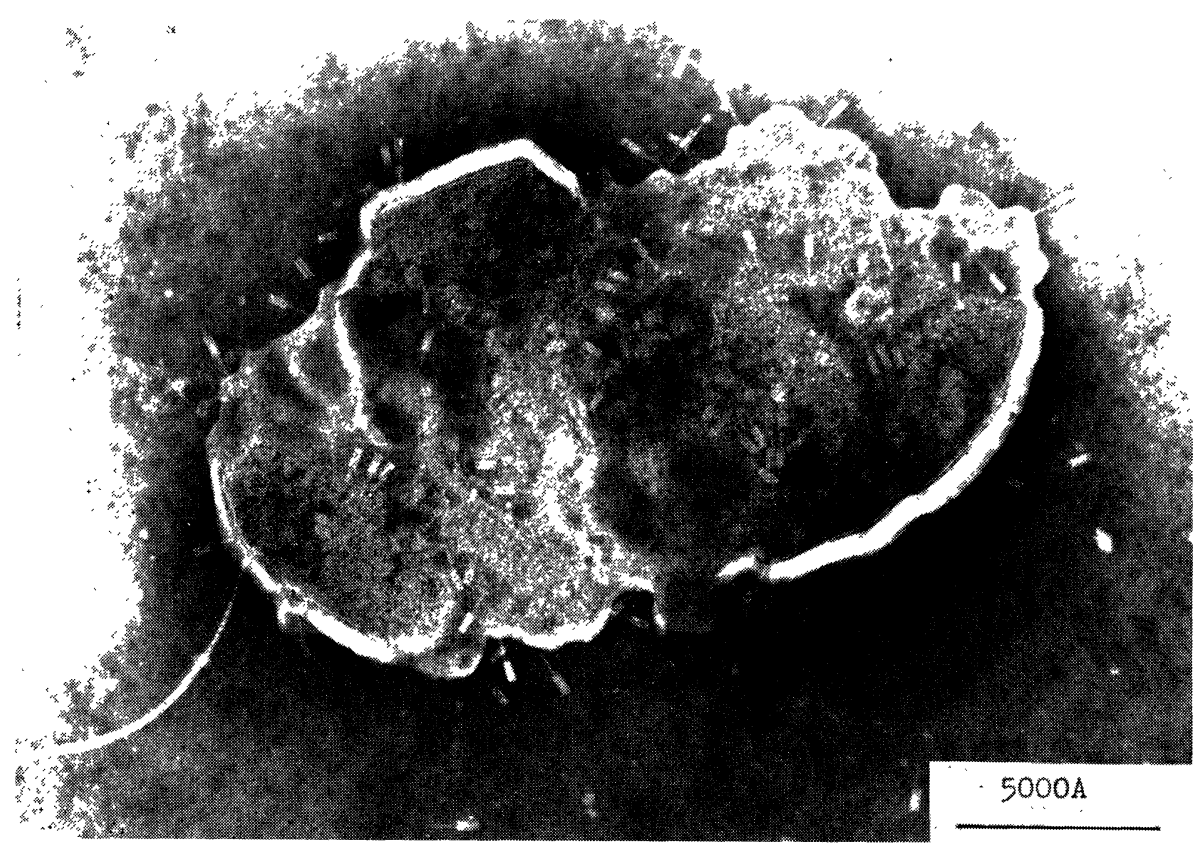

Fig. 1. An electron micrograph of pyocin $\mathrm{R}$ adsorbed on the sensitive cell.

A mixture of $1 \mathrm{ml}$ of sensitive strain P11 $\left(10^{9}\right.$ cells $\left./ \mathrm{ml}\right)$ in the nutrient broth and 0.1 $\mathrm{ml}$ of pyocin $\mathrm{R}\left(\mathrm{OD}_{280}=0.01\right)$ was incubated for $30 \mathrm{~min}$ at $37^{\circ}$. This solution was diluted 5 times with distilled water before negative staining. $(\times 45,000)$

shown in Fig. 3. A small amount of the receptor in $100 \mu 1$ was incubated with excess pyocin solution of $200 \mu \mathrm{l}$ for $30 \mathrm{~min}$ at $37^{\circ}$. Semi-linear relationship of the receptor concentration to the remaining activity of pyocin was observed, in the range of a low concentration of the receptor.

Time course of pyocin $\mathrm{R}$ inactivation by different receptor concentrations was measured at $37^{\circ}$ and $0^{\circ}$ (Fig. 4). The reaction is temperature dependent and inactivation occurred very slowly, at $0^{\circ}$ (Fig. $4 \mathrm{~B}$ ).

Effect of salt concentration on the reaction of pyocin with the receptor was examined, and the reaction was found to be highly dependent on salt concentration (Table 2). Incubation was done at various $\mathrm{NaCl}$ concentrations and $0.1-0.2 \mathrm{M} \mathrm{NaCl}$ was required for the full activity. Omission of $\mathrm{MgCl}_{2}$ from the reaction mixture did not decrease the activity appreciably.

Effect of $\mathrm{pH}$ change on the reaction is shown in Fig. 5. The dotted line shows the stability of pyocin activity reported by KAGEYAMA and EGAMI (10). Almost the same receptor activity were observed between $\mathrm{pH} 5$ and 8. 


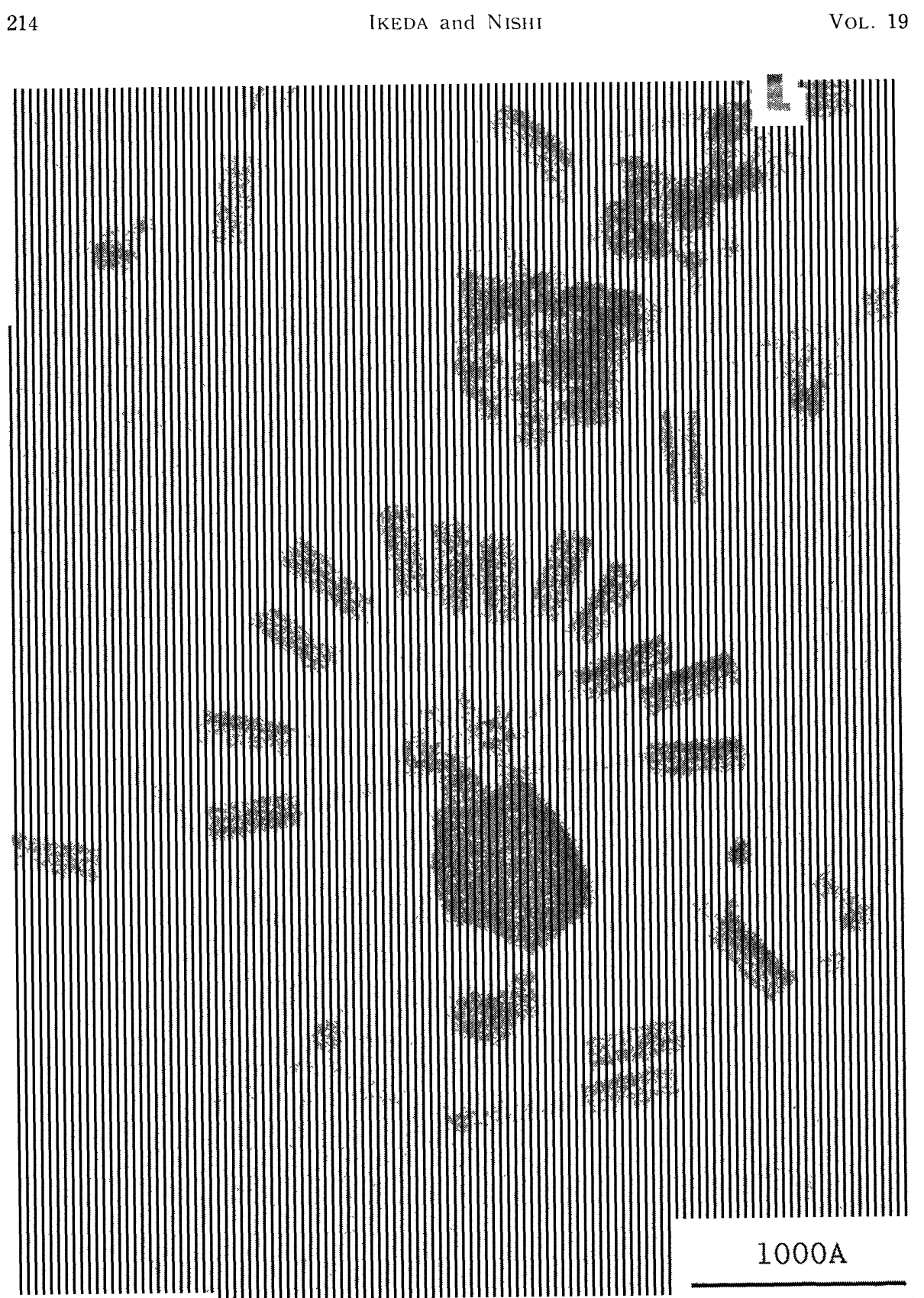

Fig. 2. 


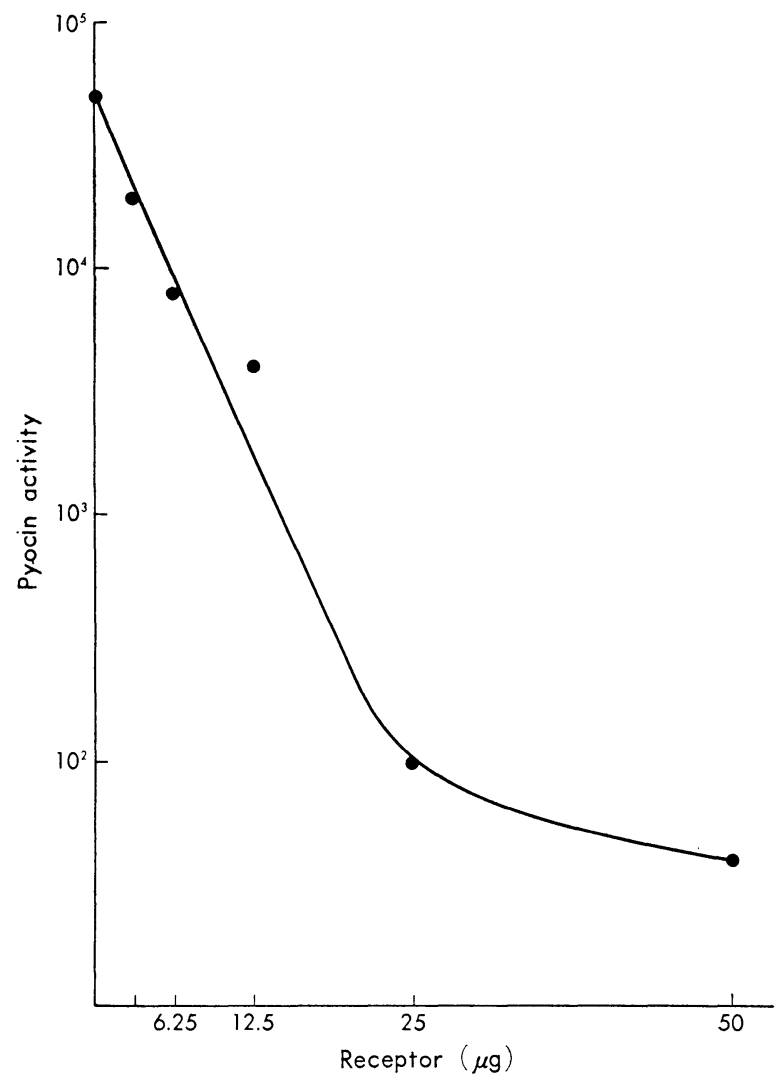

Fig. 3. Inactivation of pyocin $\mathrm{R}$ by different amounts of receptor substance.

A solution of the receptor substance (preparation $1,1 \mathrm{mg} / \mathrm{ml} 0.05 \mathrm{M}$ Tris$\mathrm{HCl}, \mathrm{pH} 7.5$ ) was serially diluted. A mixture of $100 \mu \mathrm{l}$ of this receptor solution and $200 \mu 1$ of purified pyocin $\left(\mathrm{OD}_{280}=1.35\right)$ was incubated for $30 \mathrm{~min}$ at $37^{\circ}$. Remaining pyocin activity was measured by usual assay method.

Fig. 2. An electron micrograph of pyocin $\mathrm{R}$ adsorbed on the spheroplast membrane fraction.

Spheroplast membrane fraction was prepared as described in the text. A mixture of $200 \mu 1$ this fraction (correspond to about $10^{10} \mathrm{cells} / \mathrm{ml}$ ) and $200 \mu 1$ of pyocin $\left(\mathrm{OD}_{280}=\right.$ $0.03)$ was incubated for $30 \mathrm{~min}$ at $37^{\circ} .(\times 300,000)$ 


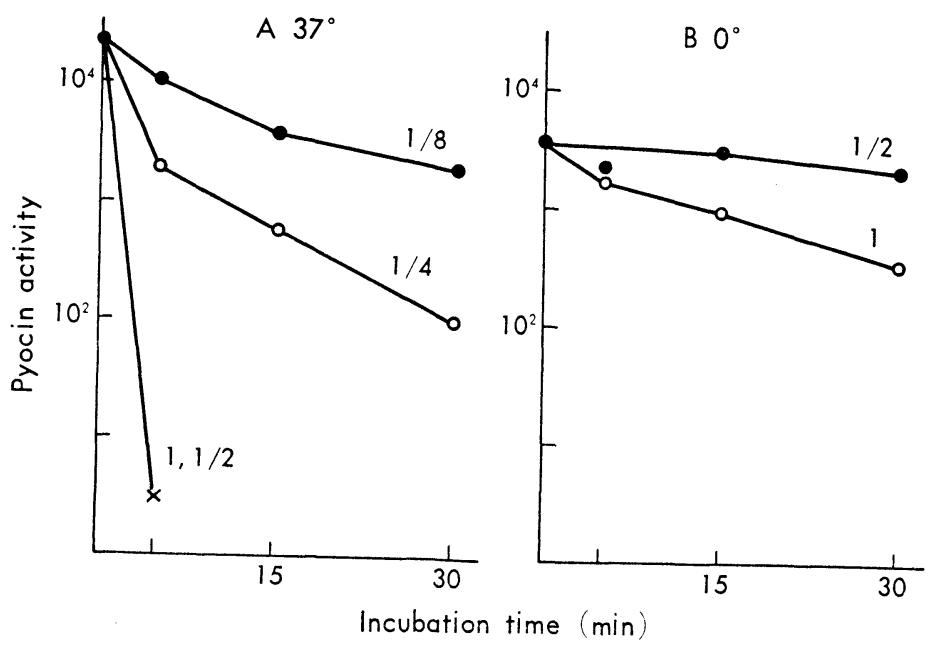

Fig. 4. Time course of inactivation reaction at $37^{\circ}$ and $0^{\circ}$.

One-tenth $\mathrm{ml}$ of the receptor substance in $0.05 \mathrm{M}$ citrate-phosphate buffer ( $\mathrm{pH}$ 6.4) was added to $0.3 \mathrm{ml}$ of purified pyocin $\left(\mathrm{OD}_{280}=0.16\right)$. After 5,15 , and $30 \mathrm{~min}$ of incubation, $0.1 \mathrm{ml}$ of the mixture was withdrawn, immediately diluted with the dilution buffer and spotted on agar plate. In the experiment $B$, dilution procedure was done at $0^{\circ}$. The experiment 1 contained $50 \mu \mathrm{g}$ of $130 \mathrm{P}$ fraction in $0.1 \mathrm{ml}$, and $1 / 2,1 / 4$, and $1 / 8$ of this amount was also used.

Table 2. Effect of salt concentration on the reaction.

Complete reaction mixture contained $0.15 \mathrm{M} \mathrm{NaCl}, 0.01 \mathrm{M}$ Tris $-\mathrm{HCl}$ ( $\mathrm{pH} \mathrm{7.5)}$ and $1 \mathrm{mM} \mathrm{MgCl}_{2}$. Receptor substance of $130 \mathrm{P}$ fraction $(1 \mathrm{mg} / \mathrm{ml})$ was serially diluted by two-fold with this solution and made up to $0.4 \mathrm{ml}$. After the addition of $0.05 \mathrm{ml}$ pyocin, the mixture was incubated for $30 \mathrm{~min}$ at $37^{\circ}$. Receptor activity was measured and shown as units per $200 \mu \mathrm{g}$.

\begin{tabular}{l|c}
\multicolumn{1}{c|}{ Additions } & Receptor activity \\
\hline Complete & 256 \\
Minus NaCl & 4 \\
$0.01 \mathrm{M} \mathrm{NaCl}$ & 16 \\
$0.025 \mathrm{M} /$ & 64 \\
$0.05 \mathrm{M} / \prime$ & 128 \\
$0.1 \mathrm{M} / \prime$ & 256 \\
$0.2 \mathrm{M} / \prime$ & 256 \\
Minus $\mathrm{MgCl}_{2}$ & 128 \\
Minus $\mathrm{NaCl},+0.1 \mathrm{M} \mathrm{KCl}$ & 128 \\
Minus $\mathrm{NaCl},+0.05 \mathrm{M} \mathrm{phosphate} \mathrm{buffer}(\mathrm{pH} 7.5)$ & 64 \\
\hline
\end{tabular}




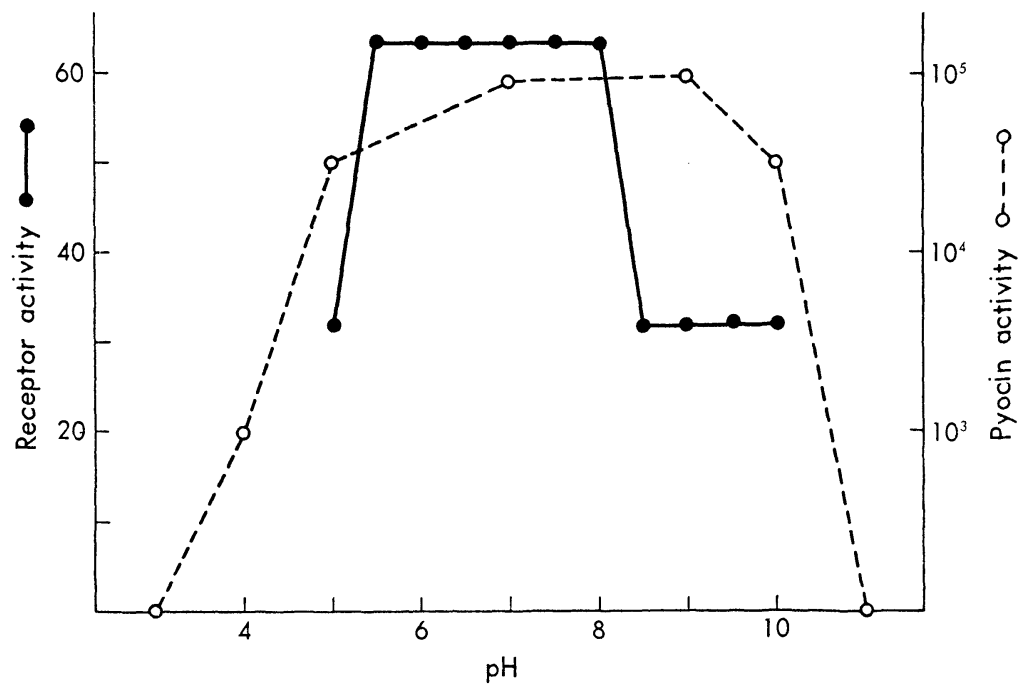

Fig. 5. $\mathrm{pH}$ Dependency of inactivation reaction.

The reaction mixture contained $0.1 \mathrm{ml}$ of $130 \mathrm{P}$ fraction $(1 \mathrm{mg} / \mathrm{ml}$ solution was serially diluted from $\times 2$ to $\times 2^{8}$ ), $0.4 \mathrm{ml}$ of $0.1 \mathrm{M}$ buffer containing $0.1 \mathrm{M} \mathrm{NaCl}$, and $0.1 \mathrm{ml}$ of pyocin. Citrate-phosphate buffer was used for $\mathrm{pH} 5-7$, Tris- $\mathrm{HCl}$ buffer for $\mathrm{pH} 7.4-9$, and carbonate buffer for $\mathrm{pH} 9.4-10$. Dotted line shows the pyocin stability curve obtained by KAGEYAMA and EGAMI ( 10 ).

\section{DISCUSSION}

In the process of $E$. coli phage infection, shrinking of tail sheath and the injection of phage DNA through the core are well known. Precise figure of T4 phage attachment was electron microscopically revealed by SIMON and ANDERSON ( 13 ). Pyocin $\mathrm{R}$ contains no nucleic acid and is considered to be a kind of defective phage $(14,15)$, although it may be classified in the category of bacteriocin.

In the present experiment, electron microscopic figure revealed the adsorption of pyocin $\mathrm{R}$ with a similar morphological change as that of the $\mathrm{T}$ even phage tail. Pyocin $\mathrm{R}$ is considered to be inactivated by adsorption, accompanied by shrinking of sheath. Pyocin $\mathrm{R}$ particle has tail fibers and a base plate like certain phage tails (12), but the participation of the fiber in the attachment cannot be recognized from our figures.

Receptor activities were solubilized by a lysozyme and EDTA treatment. This means that the receptor is located in the cell wall and consistent with the result of our previous work (5) that the chemical nature of the receptor is a lipopolysaccharide. Cytoplasmic membrane itself is considered to have no receptor activity. Although the spheroplast membrane fraction had a little activity, it may be due to the concomitant cell wall component. 
Table 3. Inactivation of phage PS5 ${ }^{a}$.

A mixture of $0.1 \mathrm{ml}$ of phage PS5 $\left(2.4 \times 10^{3}\right), 0.1 \mathrm{ml}$ of receptor substance $(130 \mathrm{P})$, and $0.3 \mathrm{ml}$ of nutrient broth was incubated for $30 \mathrm{~min}$ at $37^{\circ}$. Remaining phage number per $0.1 \mathrm{ml}$ was counted.

\begin{tabular}{c|c}
\hline Receptor added $(\mu \mathrm{g})$ & P.F.U.b \\
\hline 0 & $2.4 \times 10^{4}$ \\
10 & $1.4 \times 10^{4}$ \\
100 & $7.1 \times 10^{2}$ \\
\hline
\end{tabular}

a PS5 phage was kindly supplied by Dr. M. Kageyama.

$b$ Plaque-forming units per ml.

Molecular size required for pyocin inactivation was calculated from the result of Fig. 4. The amount of inactivated pyocin by $3.12,6.25$, and $12.5 \mu \mathrm{g}$ of the receptor was 80,128 , and $144 \mu \mathrm{g}$, respectively. The average size of the receptor equivalent for a pyocin particle was calculated as $4 \times 10^{5}, 4.9 \times 10^{5}$, and $8.7 \times 10^{5}$ daltons, taking the pyocin $\mathrm{R}$ particle size to be $1 \times 10^{7}(14)$. In this calculation, the percentage of the inactivated form of pyocin in the preparation ( 1 ), or impurity in the receptor substance (5) was not taken into account and, therefore, this value is of a very rough estimation.

Inactivation activity of pyocin receptor substance toward $P$. aeruginosa phage PS5 which attacks the strain P11 was studied (Table 3). Phage PS5 was also inactivated by this preparation, but quite a large amount of the receptor per phage was required, compared to that of pyocin.

WEIDEL et al. obtained T5 phage receptor substance from E. coli B as homogeneous particles $(7,16)$. The molecular weight of this receptor was estimated to be $1.14 \times 10^{7}$ from sedimentation and $4.2 \times 10^{7}$ from inactivation reaction. These results suggest a large difference in the receptor size between the pyocin $\mathrm{R}$ and $\mathrm{T} 5$ phages.

Pyocin $\mathrm{R}$ inactivation reaction by adsorption depends on the salt concentration and temperature. Similar properties were reported on the adsorption of phage to host cell ( 17 ).

The authors express their thanks to Drs. F. Egami and M. Kageyama of MitsubishiKasei Institute of Life Science for their continuous encouragement and discussion.

\section{REFERENCES}

1) M. Kageyama, K. Ikeda, and F. Egami, J. Biochem. (Tokyo), 55, 59 (1964).

2) Y. KAzIRo and M. TANAKA, J. Biochem. (Tokyo), 57, 689 (1965).

3) Y. KAZIRo and M. TANAKA, J. Biochem. (Tokyo), 58, 357 (1965).

4) K. IKedA and F. Egami, J. Biochem. (Tokyo), 65, 603 (1969).

5) K. Ikeda and F. Egami, J. Gen. Appl. Microbiol., 19, 115 (1973). 
6) V.W. Weidel, G. Koch, and F. LohsS, Z. Naturforsh., 9b, 398 (1954).

7) V.W. Weidel, G. Koch, and K. Bobosch, Z. Naturforsch., 9b, 573 (1954).

8) M.A. Jesaitis and W.F. Goebel, J. Exp. Med., 96, 409 (1952).

9) W.F. Goebel and M.A. Jesaitis, J. Exp. Med., 96, 425 (1952).

10) M. Kageyama and F. Egami, Life Sciences, 9, 471 (1962).

11) E. Yoshida, H. Takahashi, and B. Maruo, J. Biochem. (Tokyo), 53, 124 (1963).

12) S. Ishir, Y. Nishi and F. Egami, J. Mol. Biol., 13, 428 (1965).

13) L.D. Simon and T.F. Anderson, Virology, 32, 279 (1967).

14) M. Kageyama, J. Biochem. (Tokyo), 55, 49 (1964).

15) M. Kageyama, In The Different Slices of Biochemistry, ed. by S. Suzuki et al., Kodansha Ltd., Tokyo (1972), p. 484, in Japanese.

16) V.W. Weidel and E. Kellenberger, Biochim. Biophys. Acta, 17, 1 (1955).

17) M.H. ADAMS, Bacteriophages, Interscience Publishers, Inc., New York, p. 137 (1959). 